\title{
Impact of the coronavirus pandemic on the aviation industry in Uzbekistan
}

\author{
Donier NIMATOV1, Dilfuza IMAMOVA² \\ University of World Economy and Diplomacy
}

\begin{tabular}{l} 
ARTICLE INFO \\
\hline Article history: \\
Received April 2021 \\
Received in revised form \\
20 April 2021 \\
Accepted 15 May 2021 \\
Available online \\
25 June 2021
\end{tabular}

\section{Keywords:}

the coronavirus pandemic, aviation industry,

new perspectives,

anti-crisis measures,

air transport,

state.

\begin{abstract}
The article analyzes the impact of the undertaken anti-crisis measures based on the analysis of the volumes of transported goods, the problems of the industry in the current circumstances caused by the coronavirus pandemic in the world are characterized. Specific measures have been formulated to mitigate the negative impact on economic development.
\end{abstract}

2181-1415/C) 2021 in Science LLC.

This is an open access article under the Attribution 4.0 International (CC BY 4.0) license (https://creativecommons.org/licenses/by/4.0/deed.ru)

\section{Коронавирус пандемиясининг Ўзбекистоннинг авиация саноатига таъсири}

\footnotetext{
Калит сўзлар:

коронавирус пандемияси, авиация саноати, янги истиқболлар, инқирозга қарши чоралар, хаво транспорти, давлат.
}

\begin{abstract}
АННОТАЦИЯ
Мақолада ташилаётган товарлар хажмини тахлил қилиш асосида қабул қилинган инқирозга қарши чораларнинг таъсири тахлил қилинади, дунёда коронавирус пандемияси келтириб чиқарган хозирги шароитда соха муаммолари тасвирланган. Иқтисодий ривожланишга салбий таъсирни юмшатиш бўйича аниқ чора-тадбирлар ишлаб чиқилган.
\end{abstract}

\footnotetext{
${ }^{1}$ Master, University of World Economy and Diplomacy. Tashkent, Uzbekistan.

${ }^{2}$ Candidate of legal Sciences (PhD), Assistant Professor, University of World Economy and Diplomacy, Tashkent, Uzbekistan.
} 


\section{Влияние пандемии коронавируса на авиационную отрасль Узбекистана}

\author{
Ключевые слова: \\ пандемия коронавируса, \\ авиационная \\ промышленность, \\ новые перспективы, \\ антикризисные меры, \\ воздушный транспорт, \\ государство.
}

\begin{abstract}
АННОТАЦИЯ
В статье дан анализ влияния предпринятых антикризисных мер на основе анализа объемов перевозимых грузов, охарактеризованы проблемы отрасли в сложившихся обстоятельствах, вызванные пандемией коронавируса в мире. Сформулированы конкретные меры по смягчению негативного влияния на развитие экономики.
\end{abstract}

UNWTO strongly stated "Stay at home today. Start tomorrow". Containing the pandemic is our top priority, and tourism is committed to supporting all measures taken to contain the outbreak. However, these measures have led to the fact that the tourism sector has become one of the most difficult to access, and this has huge consequences for the economy of the whole world [1]. Tourism is an economic engine and one of the main pillars of supporting global growth and development. It accounts for $30 \%$ of global service exports and 1 for every 10 jobs in the world. Regardless of the economic classification of low-, middle - or high-income countries, the contribution of tourism is multi-level and cross-sectoral [2]. It is also a vital source of employment, especially for women and youth, as well as income from tourism and foreign direct investment. The closure of the external and internal borders in March this year not only reduced the revenues of tourism companies to zero, but also led in some cases to significant losses. Many companies in the country face the threat of bankruptcy of hotel, transport, as well as catering, sightseeing and consulting services in the field of tourism[3].

At present, worldwide, the spread of the COVID-19 coronavirus infection has caused a number of problems, not only with domestic contractual relations, but also greatly affecting foreign trade and foreign economic relations between foreign partners [4], as well as the transport industry through air transport.

Despite the fact that COVID-19 coronavirus infections were spread all over the world at the beginning of 2020, foreign economic contracts have not stopped, but their volume has decreased. Although there were problems associated with the inability to fulfill obligations under previously concluded foreign economic contracts. This, in turn, has also had a significant impact on the foreign economic relations of many countries due to the established internal restrictions [5] in various sectors and, of course, in aviation, a sharp decline in their revenues, in particular restrictions on flights to carry passengers and luggage. All this shows the need for special attention in this sector.

Losses in the volume of passenger and cargo transportation within the republic and beyond its borders can undoubtedly significantly slow down the growth of the economy of Uzbekistan. During the antiviral measures, an anti-crisis fund [4] was created to support entrepreneurship, infrastructure projects, and the leading sectors of the republic's economy, including tourism and transport. As a priority measure, a commission has been established in Uzbekistan to study the situation in the country and abroad in connection with the spread of this type of coronavirus [6]. 
According to forecasts of experts in the tourism industry of Uzbekistan, losses amounted to up to 31 million US dollars [7], all this led to the idleness of the country's aviation sector and to large financial losses, both for the state and for the private sector. In order to prevent bankruptcy, the sector was provided with a number of preferences: debt on loans without accrual of penalties, revision loan repayment schedules for Uzbekistan Airways JSC, exemption from payment of land tax and property tax, and payment of social tax at a reduced rate of 1 percent [8].

When analyzing the main indicators of transport for the 1st quarter of 2020, the dynamics shows a decrease in traffic volumes due to the restrictions imposed by some countries on air traffic in transit traffic $-52.5 \%$. For example, in the 1st quarter of this year, indicators for air (export and import) modes of transport had a stable growth rate compared to the same period last year, then already in 20 days of April in the peak quarantine period, there is a sharp decrease in all types of communication [9]. Most countries in the world have imposed restrictions on air traffic, due to a sharp drop in passenger traffic and non-payment of airlines and tenants, airports lose $90 \%$ of revenue, while costs remain unchanged. These and other factors make the aviation industry one of the most vulnerable in the face of the economic crisis due to the coronavirus pandemic in the world.

One hundred and ten countries significantly restricted air traffic, which accounted for about $98 \%$ of the aviation market. Passenger traffic recovery forecasts are pessimistic. There are many reasons for such pessimism in forecasts. COVID-19 has caused a global economic recession, a decline in international trade that will affect the airport industry. Business activity went online due to quarantine, in addition to this, business will cut travel budgets in the future. The growth of passenger traffic will also be constrained by the requirements for observing the distance between passengers in the terminal and the plane, new visa restrictions, as well as concerns of the passengers themselves [10].

Airports formed a consolidated industry position on the package of measures and turned to the government for support. The set of measures includes state guarantees for the ten largest airlines to fulfill their obligations for the period from April 1 to December 31,2020 , full or partial subsidies for the cost of airport services and fuel complexes for airlines, the abolition of rent for the use of state airfield infrastructure for 2020, and also tax deferrals and incentives, financial incentives for staff retention, and suspension of dividend payments to the government where applicable [11].

A number of states have released amounts equal to $11 \%$ of GDP to support the economy, a considerable part of which is to support the airport industry. Canada released US \$ 331 million to support the airport industry, US \$ 58 billion, Singapore US \$ 7 billion, New Zealand US $\$ 4$ billion, etc. [12].

The most effective measures to support the airport industry are tax incentives and government guarantees. KPMG experts named the most effective and most feasible measures to support the airport industry. In their opinion, such measures are tax incentives for the industry and the provision of state guarantees to independent players in the industry, primarily airlines. When passenger traffic begins to recover, this will help overcome the crisis of confidence in the industry and gain the highest possible pace for the situation [13]. 
In order to improve the quality of passenger service and ensure flight safety, over the past few years, the national aircraft fleet has been replenished with new modern aircraft "Airbus" and "Boeing". With the involvement of experts from the World Bank, the work on the distribution of functions for air transportation and airport operations between independent enterprises was completed on the basis of international best practices. In October 2019, the reorganization of the NAC "Uzbekiston Havo Yollari" was carried out. The independent companies "Uzbekistan Airways" and "Uzbekistan Airports" were created.

In order to further liberalize the aviation market and expand the geography of flights, from October 2019, the "Open Skies" regime was introduced at the international airports of Karshi, Nukus, Termez and Bukhara. However, we note that the introduction of the "open skies" regime in itself is not a key factor in the immediate increase in the number of foreign flights and the rapid growth of passenger traffic.

It is expected that the measures taken will increase the attractiveness of the aviation sector of our country for foreign air carriers. The construction of a new passenger terminal and a runway of the Samarkand International Airport is envisaged, which will increase the airport's capacity from 500 passengers to 1500 passengers per hour. As a result of the optimization and reconstruction of the Tashkent International Airport with the participation of German specialists, the airport's capacity will be increased from 4 million to 7 million passengers per year. The construction of a new runway at the Termez International Airport and the reconstruction of the Andijan International Airport will also provide the ability to service all types of aircraft and increase the number of flights by 2-3 times [14].

In our opinion, over the past 30 years, there have been practically no reforms in this industry. As a result, serious problems and deep contradictions have accumulated. Not enough attention was paid to the development of the industry; it developed on the principles of monopoly in the absence of competition. As a result, we see high rates and insufficient quality of services provided.

\section{REFERENCES:}

1. UNWTO Call for Action for Tourism's COVID 19 Mitigation and Recovery, published 1 April 2020// [Electronic resource]:https://www.unwto.org/news/unwtolaunches-a-call-for-action-for-tourisms-covid-19-mitigation-and-recovery.

2. UNWTO "Supporting jobs and economies through travel \& Tourism" 2019. // [Electronic resource]: https://www.unwto.org/recommendations-for-recovery-covid-19.

3. Ачилова Л.И. Влияние covid-19 на гостиничные услуги: национальный и зарубежный опыт. // Review of law sciences. 2020 - C. 96-101. [Electronic resource]: https://cyberleninka.ru/article/n/vliyanie-covid-19-na-gostinichnye-usluginatsionalnyy-i-zarubezhnyy-opyt

4. Имамова Д.И. Влияние пандемии на внешнеэкономические сделки//. Review of law Sciences. Вестник юридических наук. - Ташкент, 2020. Спец номер. - C. 139.

5. Imamova D.I. Improvement of legal regulation of foreign economic transactions in the Republic of Uzbekistan. // Society and innovations. Общество и инновации. Ташкент, 2020. - № 2. - С. 97.

6. Указ Президента Республики Узбекистан от 19 марта 2020 года № УП-5969 «0 первоочередных мерах по смягчению негативного воздействия на отрасли экономики коронавирусной пандемии и глобальных кризисных явлений». // [Electronic resource]: https://lex.uz/ru/docs/4770763. 
7. Распоряжение Президента Республики Узбекистан от 29 января 2020 года №P-5537 «Об образовании Специальной республиканской комиссии по подготовке Программы мер по предупреждению завоза и распространения нового типа коронавируса в Республике Узбекистан». // [Electronic resource]: https://www.lex.uz/docs/4720408.

8. Данные Всемирной туристической организации. // [Electronic resource]: https://www.unwto.org/tourism-covid-19.

9. Указ Президента Республики Узбекистан от 3 апреля 2020 года №УП-5978 «0 дополнительных мерах поддержки населения, отраслей экономики и субъектов предпринимательства в период коронавирусной пандемии». // [Electronic resource]: https://lex.uz/ru/docs/4780477.

10. Министерство транспорта Республики Узбекистан. // [Electronic resource]: https://www.mintrans.uz/ru/

11. Transport infrastructure on the African continent. Prospects for the implementation of joint projects// [Electronic resource]: https://roscongress.org/sessions/africa-2019-transportnaya-infrastruktura-naafrikanskom-kontinente-perspektivy-realizatsii-sovmestnykhproektov/search/\#00:04:11.904

12. The impact of epidemics on the economy. The role of public-private partnerships in the fight against the Ebola virus. // [Electronic resource]: Experience and perspectives https://roscongress.org/sessions/vliyanie-epidemiy-na-ekonomiku-rol-gosudarstvennochastnogo-partnerstva-na-primere-borby-s-virusom-e/search/\#00:27:25.344.

13. Transport of Russia: ensuring the development of trunk infrastructure as the basis for economic growth // [Electronic resource]: https://roscongress.org/sessions/iif2019-transport-rossii-obespechenie-razvitiya-magistralnoy-infrastruktury-kak-osnovyrosta-ekonomiki/search/\#01:00:33.407.

14. Reforms in the development of civil aviation in Uzbekistan // [Electronic resource]: $\quad$ https://www.uzairways.com/ru/press-center/news/reformy-v-sfererazvitiya-grazhdanskoy-aviacii-uzbekistana. 